\title{
Subsistence Hunting of Podocnemis Lewyana and Rhinoclemmys melanosterna (Testudines) in the Region of the lowSan Jorge River, Caribbean, Colombia
}

\author{
Jaime De La Ossa-V*, Alexander Pérez-Cordero and Donicer Montes-Vergara \\ Facultad de Ciencias Agropecuarias, Departamento de Zootecnia, Universidad de Sucre, Colombia; \\ jaime.delaossa@unisucre.edu.co, alexander.perez@unisucre.edu.co, donicer.montes@unisucre.edu.co
}

\begin{abstract}
Objective: We have evaluated aspects related with the subsistence hunting of Podocnemis Lewyana and Rhinoclemmys melanosterna, chelonians that inhabit the wetlands of the low San Jorge River in the Colombian Caribbean. Methods/ statistical Analysis: During the first four months of 2018, representative sample of 83 resource extractivists and the information was collected through the survey method; the capture effort was calculated; for the population parameters, the number of individuals and the total length of the carapace were taken into account. The socioeconomic aspects linked to the use of the resource were characterized and also included descriptive statistic and the Kruskal Wallis test. Findings: It is determined that both the turtle hunt as well as its commercialization is significantly carried out by people of the male sex. The effort of capture has very high comparative values, which indicates for P. lewyana, that its populations are deteriorated, aspect that is corroborated, because the capture was minimal and composed only with juvenile animals. The methods of capture, in general, are harmful for the animal, even, as in the case of the burning of pastures, highly impacting. Evidence obtained indicates that the use of R. melanosterna, consumed exclusively in the diet of the hunters, because it is a species without commercial appreciation, is a new variant of the substitution effect, which occurs because the species of chelonians with Sale value is marketed and those that are not eaten. Application: Knowledge of the ecological and social aspects that are involved in the use of wildlife is a valuable input to advance conservation programs; especially when it comes to chelonians.
\end{abstract}

Keywords: Caribbean, Colombia, Continental Chelonians, Population Status, Utilization

\section{Introduction}

The basin of the lower San Jorge River, in the department of Sucre, south Caribbean of Colombia, is part of the so-called ecoregion of the Mojana, which is characterized by being a wetland area belonging to the Depression Momposina and as such act in the water regulation of the three great rivers of the Colombian Caribbean basin: the Magdalena, the Cauca and the San Jorge ${ }^{1}$.

The zone in question is widely known for its richness in continental chelonians, with the presence of six species: Trachemys callirostris, Kinosternon scorpiodes, Batrachemys dahli, Podocnemis lewyana, Rhinoclemmys melanosterna and Chelonoidis carbonaria ${ }^{2-3}$; In addition, there are records of the patterns of use given, with special emphasis for T. callirostris, without this meaning that the other species of turtles present there are not subject to use $\frac{4-6}{6}$, since all are exposed to anthropogenic tensions, such as: deterioration of habitat, hunting and illegal trafficking

Podocnemis Lewyana (Duméril, 1852) (Testudines: Podocnemididae), known as Magdalena River Turtle and

${ }^{*}$ Author for correspondence 
regionally with Tortuga de Rio. It has a wide distribution in Colombia, it occupies the Caribbean, Magdalena and Cauca hydrographic zones, up to 800 m.s.n.m; Its national status is cataloged as Critically Endangered (CR), globally according to Tortoise and Freshwater Turtle Specialist Group, 1996 as EN A1bd² ${ }^{2}$ in addition to being considered in the red list of IUCN as critically endangered A2acd + 4acd 10 (Figure 1).

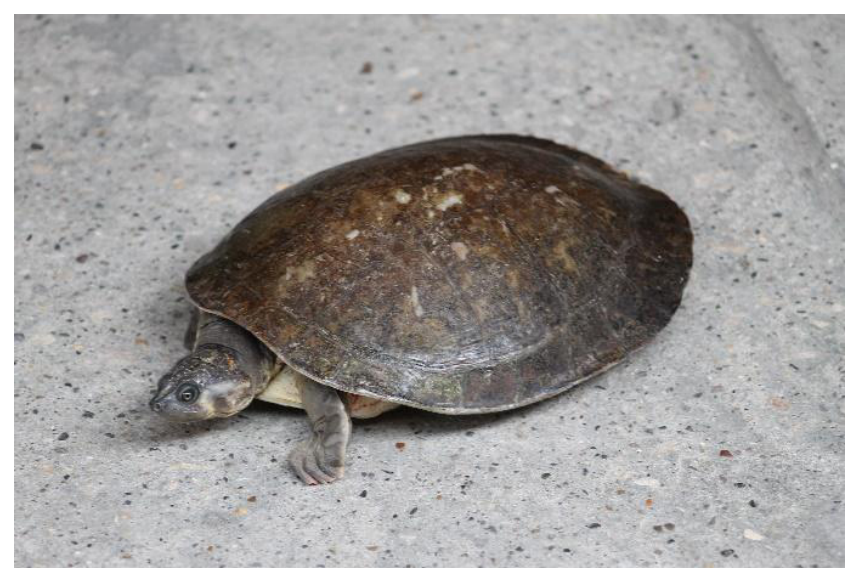

Figure 1. Juvenile specimen of P. lewyana captured in the study area. Author: Jaime De La Ossa-V.

Rhinoclemmys melanosterna (Gray, 1860) (Testudines: Geoemydidae), known as Brown Wood Turtle, Brown Land Turtle, Furrowed Land Terrapin and regionally with palmera or hicoteafinaoccurs in Colombia, Costa Rica, Ecuador, Honduras, Nicaragua and Panama.In Colombia this species is recorded along the Pacific Coast, the western and central zone of the Atlantic Coast, on the Magdalena River to Lebrija, Santander ${ }^{11}$. According to Red List Category and Criteria (Tortoise and Freshwater Turtle Specialist Group, 1996) their status is Lower Risk / Near Threatened (NT) $\underline{12}$ (Figure 2).

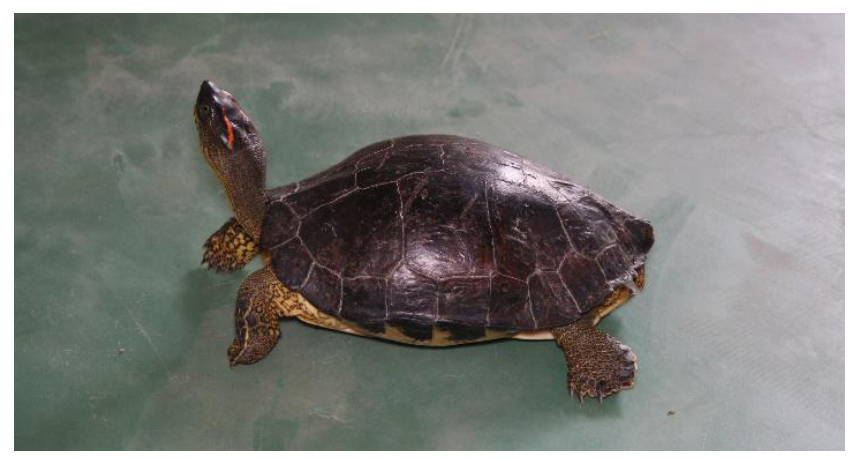

Figure 2. Adult specimen of $R$. melanosterna captured in the study area. Author: Jaime De La Ossa-V.
Subsistence hunting is considered a legal option valid in Colombia (Decree 1608 of 1978), and is exercised by human groups whose socioeconomic conditions are precarious and live in places where the resource is available; it is normatively established that it does not require a permit but it must be practiced in such a way that the resource is not damaged. However, this activity causes deterioration and local extinction of wildlife populations in many parts of the world, and is considered the second most important threat to sustainability in many tropical ecosystems $\frac{13-16}{}$, especially if combines self-consumption with commercialization ${ }^{5}$.

Finally, having the genera of chelonians most trafficked in Colombia is: Trachemys, Chelonoidis, Kinosternon, Podocnemis and Rhinoclemmys ${ }^{2}$. In addition, they are captured for illegal consumption and sale as pets, as well as supporting strong habitat destruction and other human impacts such as contamination of bodies of water and desiccation of flood zones for agricultural use $\mathrm{s}^{-}$. Reasons that justify the need to investigate the use given to the two species treated in this study, as well as analyze some population data, which becomes a contribution to knowledge and support for the conservation tasks that are needed.

\section{Materials and Methods}

\subsection{Studio Zone}

Low San Jorge river, belonging to the ecological region of La Mojana, Sucreña, municipality of San Benito Abada

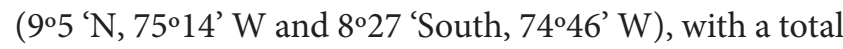
area of $1,434 \mathrm{~km} 2$, of which $45 \%$ is a flood zone, composed of a winding set of wetlands. Ecologically it is a transition between tropical dry forest and very humid tropical forest $\frac{17}{}$. The geographic location of the sampling sites is presented in Table 1 .

Table 1. Sampling sites within the study área

\begin{tabular}{lll}
\hline Place & North & West \\
\hline 1. & $9^{\circ} 55^{\prime} 41^{\prime \prime}$ & $75^{\circ} 58^{\prime} 49^{\prime \prime}$ \\
2. & $8^{\circ} 52^{\prime} 58^{\prime \prime}$ & $75^{\circ} 58^{\prime} 04^{\prime \prime}$ \\
3. & $8^{\circ} 50^{\prime} 52^{\prime \prime}$ & $75^{\circ} 03^{\prime} 25^{\prime \prime}$ \\
4. & $8^{\circ} 54^{\prime} 17^{\prime \prime}$ & $74^{\circ} 58^{\prime} 04^{\prime \prime}$ \\
\hline
\end{tabular}

\subsection{Field Work}

Information gathering was carried out during the first four months of 2018, a period of drought and greater use 
of chelonians in the area. Two weekly samplings were made, for a total of 32 samplings, of each of the two species of this study.

At the beginning of the sampling, the first person was selected at random and then the Snowball criterion was applied, with the purpose of using as many references as possible $^{\frac{18}{8}}$. Semi-structured surveys were applied as the main instrument for obtaining the required utilization information, in terms of catches, utilization and trade ${ }^{19}$. A total population of extractivists of 83 people was determined, the representative sample was of 39 people ( $p=$ $0.05,95 \%$ alpha, $d=5 \%)$. The turtles were identified and measured in the total length of the carapace (LTC) ${ }^{20}$; likewise, information was collected regarding the methods of capture that were used. The effort measure used was determined by the number of individuals captured by species in relation to the time spent: (Capture Effort) EC $=$ NIC $/ \mathrm{T}$ : where, NIC $=$ Number of individuals captured by species, $\mathrm{T}=$ Time spent $\underline{21}$.

\subsection{Data Analysis}

The data was grouped into tables according to the information obtained and the nature of the answers. The mean, minimum, maximum and standard deviation were calculated for the individuals captured by species; As for the extraction sites and the number of individuals captured per species, the Kruskal Wallis test was applied $\underline{22}$.

\section{Results}

The most relevant social aspects regarding the group of people and discriminated by sex, participating in the surveys, are presented in Table 2. It is determined that all of the men work in agricultural work as temporary employees of the cattle farms of the region, activity that combine with fishing and hunting; while women are engaged in housework.

Table 2. Social aspects of the group of interviewees

\begin{tabular}{|c|c|c|c|c|}
\hline Variables & Men & $\%$ & Women & $\%$ \\
\hline Surveyed & 30 & 76.9 & 9 & 23.1 \\
\hline Illiteracy & 12 & 30.7 & 5 & 12.8 \\
\hline $\begin{array}{l}\text { Participation in the } \\
\text { capture }\end{array}$ & 30 & 76.9 & 2 & 5.1 \\
\hline Preparation as food & 0 & 0 & 9 & 100 \\
\hline Commercialization & 24 & 71.8 & 4 & 10.2 \\
\hline
\end{tabular}

In Table 3, the data of total catch by species and by place of work are presented.

Table 3. Total catch by species and by place

\begin{tabular}{lcc}
\hline Place & P. lewyana & $R$. melanosterna \\
\hline 1 & 0 & 15 \\
2 & 2 & 8 \\
3 & 2 & 9 \\
4 & 1 & 12 \\
\hline Total & $\mathbf{5}$ & $\mathbf{4 4}$ \\
\hline
\end{tabular}

The mean sizes taken in their LRC dimension, for the samples sampled were: P. lewyana $22.6 \mathrm{~cm}$ (18-30) SD 4.9; for R. melanosterna 22.5 (15-27) SD 3.03. For both $P$. lewyana and $R$. melanosterna, when applying Kruskal Wallis test no significant differences were observed between place and number of individuals captured: $(\mathrm{H}$ $(10, \mathrm{~N}=44)=5.579398 p=, 8493)$ and $(\mathrm{H}(10, \mathrm{~N}=44)=$ $5.579398 p=, 8493)$, respectively.

The methods of capture were basically four: fishing with hooks; use of harpoon; "Beat" which consists of hitting with branches or sticks the banks of the bodies of water so that the animals run away and thus be able to capture them manually; and burning, which involves setting fire to the banks with dry vegetation so that the animals leave their shelters. For P. lewyana they are used as hook and harpoon capture methods; while for R. melanosterna the four capture methods described are practiced. Table 4 shows the total percentage results of the methods used for the capture according to the species.

Tabla 4. Methods of capture used by species

\begin{tabular}{lcccc}
\hline \multirow{2}{*}{$\begin{array}{l}\text { Capture } \\
\text { method }\end{array}$} & \multicolumn{2}{c}{ P. lewyana } & \multicolumn{2}{c}{ R. melanosterna } \\
\cline { 2 - 5 } & $\mathbf{N}$ & $\mathbf{\%}$ & $\mathbf{N}$ & $\mathbf{\%}$ \\
\hline Fish hook & 3 & 23,1 & 21 & 40.4 \\
Harpoon & 10 & 76,9 & 15 & 28.8 \\
"Apaleo" & 0 & 0 & 12 & 23.1 \\
Burning & 0 & 0 & 4 & 7.7 \\
\hline Total & $\mathbf{1 3}$ & $\mathbf{1 0 0}$ & $\mathbf{5 2}$ & $\mathbf{1 0 0}$ \\
\hline
\end{tabular}

For the determination of the hunting effort by species according to the data provided by the extractivists, we obtained: P. lewyana, spent 80 hours and a catch of 5 specimens, $\mathrm{EC}=0.062$ Ind / day; for R. melanosterna, they spent 120 days and a catch of $43, \mathrm{EC}=0.358$ Ind / day. 
Regarding the use of the turtles, it is determined that they capture them for their own food, although sometimes they sell them, only if the opportunity arises and someone especially is interested in acquiring them. In their totality they state that 20 years ago the catches of P. lewyana were abundant and that the specimens were adults, of very good size and very appreciated commercially, which at present does not occur; because of the intensive use and deterioration of the bodies of water where it lives.

Regarding $R$. melanosterna, they indicate that their catches are sporadic, that it is a turtle that does not have commercial preference, that in the areas of aquatic herbaceous plants and streams still subsist populations, since their extraction is not an economically profitable activity and that they have been used for a few years for family feeding, given the lack of other chelonians or other wildlife species that were used, such as: Hydrochoerus hydrochaeris (Capybara), Mazama americana (Red Brocket), Dendrocygna viduata (White-faced Whistlingduck) and Cairina moschata (Muscovy Duck), among others; also because the populations of the fish species in general are very depleted and what is captured is very small and scarce.

On the other hand, they argue that the use of R. melanosterna at a family and non-commercial level is also due to the fact that Trachemy scallirostris, another species of tortoise in the area, is still commercially preferred and when captured it is better to sell it than consume it. Likewise, it justifies hunting as a right that they have as inhabitants of the region and for the cultural tradition they possess.

\section{Discussion}

The social and economic information of the people who participated in this investigation agrees with what is established for this area of Colombia; nevertheless, the illiteracy rate is higher in percentage terms than the national average ${ }^{23-24}$. On the other hand, women are significantly outside of hunting activities and the commercialization process, which is regularly presented for this type of extractive activity in other countries and even within Colombia $25-27$.

The catch with hooks is used for many species of chelonians; nylon lines are used with several hooks installed at a regular distance, they are fattened with pieces of fish or chicken in the process of decomposition $\frac{28}{2}$; It is a highly damaging technique, since in many occasions it is impossible to remove it due to the type of hook attachment, it also causes severe injuries because the animal feels trapped struggling to free itself, these specimens are used quickly for food.

The use of harpoon is a method of capturing chelonians, which involves damage to the carapace of the animal; generally they are specimens that cannot be kept alive for a long time. It is used in animals of medium to large size; it is applied to the stalking hunter, allowing the animal to approach or to see signs of its presence, for example bubbling or movements in the water while consuming baits that are placed for that purpose $e^{28}$.

The "apaleo" is a technique that is based on producing a disturbance in the area of refuge of the animal, which seeks to avoid an alleged danger and flee, thereby offering the opportunity to be captured manually or with Meshes because it becomes visible. "Zangarreo" consisting of stirring the water of the banks or under the aquatic vegetation; in the rivers or swamps in the rock formations where the animal seeks refuge, the water that opens space is hit, in such a way that fish are forced out to be trapped in the extended nets ${ }^{29}$.

The burning of peripheral banks or grasslands to bodies of water is documented for the capture of T. callirostris ${ }^{30}$, it is perhaps the capture technique that has the greatest cruelty, and its negative impact is broad spectrum, since it destroys clutches and animals that are in the estivación, in addition to the damages that occasionally to all the biota there present.

The calculation of the capture effort makes it possible to detect population trends or changes in the size of the populations $\frac{31-33}{}$; In addition, the capture effort shows the quality of natural reserves and their deterioration, especially when compared with historical data or with perceptions of abundance that resource users have. The capture effort obtained for P. lewyana, is greater when compared to the results obtained for the Prado River, south east of Colombia, where 110 turtles were captured in 14 sampling hours for a total of 7.9 turtles.

As for R. melanosterna, there are no records of abundance for the area; it is known that they can be located in aggregations of up to 18 individuals in caves that form under the roots of large trees, which allows us to infer abundance greater than what was found in this study. However, it must be added that the average size of the specimens studied shows that they are adults, since the maximum length for the species is $30 \mathrm{~cm}$ of total length of 
the carapace 2 , which means that populations are in relative good condition.

The high effort of capture that in this work was obtained for both species, it would be explained if it is taken into account that the abundance of the turtles can be affected by habitat degradation, differences or preferences of the same, seasonal changes, geographical variability and conditions local of each river; in addition to commercial exploitation $\frac{33}{}$.

The use of R. melamosterna for extractivist consumption, given that it does not yet have commercial demand, indicates that the so-called substitution effect is being presented ${ }^{21}$; except that in this case, contrary to what was found for the Negro River, Amazonas Brazil21 , the reasons are not strictly for the deterioration of the populations of the preferred species, but rather it acquires a commercial connotation, where self-consumption is oriented towards a substitute species, because the other of greater appreciation and commercial character, Trachemy scallirostris, provides the necessary economic income.

It is noted, with respect to T. callirostris, that even its populations are productive in terms of extraction, although for about 15 years there has been a decrease in catches and a reduction in the average size of the animals hunted $\stackrel{4-5}{ }$. Even so, hunting and trade persist. Related data for the Mojana ecoregion indicate an annual catch of $1,000,000$ copies $^{34-35}$.

For its part, it is established, according to information from the respondents, that P. lewyana is a preferred species for consumption, however, the catches are minimal and in this study only juveniles were observed, the maximum size for the species is $48 \mathrm{~cm}$ of total carapace length $\underline{2}$. Note, that exemplary that is hunted, even being a juvenile, without any problem is sold, because it is an animal desired as food.

The exploitation of wildlife for economic purposes, in Colombia, has deep roots and it is known that its indiscriminate use has generated great impact on natural populations, particularly those with a strong cultural demand, whether for medicinal or gastronomic uses., to the point that some of them have been brought to the brink of extinction or have disappeared locally from many areas of the country $\frac{36}{6}$; chelonians are not the exception and are one of the groups most trafficked for consumption $\frac{5,7,8}{}$; In addition, there is a strong cultural component regarding the use of chelonians as food ${ }^{2}$. Finally, there is a perception on the part of the extractivists that the practice of hunting is justified, not only because it is a subsistence mechanism, but also because it is a traditional activity from which their income derives ${ }^{37}$.

\section{Conclusions}

The effects exerted by the communities in their activities of hunting, consumption and commercialization of chelonians, for the study area, are the result of strong and negative pressures of social, economic and environmental order, in this case the basic extractivism as subsistence alternative it can lead to local extinction and then to total extinction.

The deterioration of the populations of $P$. lewyana found in this work requires a greater investigative effort, as it needs as a matter of priority that for the zone and the species of turtles linked to consumption and illegal trade, conservation projects be established and areas are defined for their protection.

The substitution effect, according to the results analyzed, takes on a new expression, not only occurs because the natural inventory is depleted or depleted, but because there is a demand that allows monetary income with the sale of preferred species, while self-consumption is exercised over those with less in the commercial appreciation announcement. In this case, then, there is on the one hand subsistence hunting and on the other, illegal hunting and trafficking; activities that synergistically create a greater environmental impact.

\section{References}

1. Aguilera Díaz MM. La Mojana: Riqueza natural y potencial económico. Documentos de trabajo sobre economía regional, Banco de la República de Colombia: Cartagena. 2004; 48:1-73.

2. Rueda-Almonacid JV, Carr JL, Mittermeier RA, RodríguezMahecha JV, Mast RB, Vogt RC, Rhodin AG, De La Ossa J, Rueda JN, Goettsch-Miteremeier C. Las tortugas y los cocodrilianos de los países andinos del trópico. Conservación Internacional Colombia: Bogotá; 2007.

3. Páez VP, Morales BMA, Lasso CA, Casta-o Mora OV, Bock BC. V. Biología y conservación de las tortugas continentales de Colombia. Serie Editorial Recursos Hidrobiológicos y Pesqueros Continentales de Colombia. Instituto de Investigación de Recursos Biológicos Alexander von Humboldt: Bogotá; 2012.

4. Fuentes-Obeid S, Sampedro MA, Ardila-Marulanda M. Importancia de la jicotea (Trachemys scriptacallirostris: Chelonia, Emydidae) como recurso natural en la comuni- 
dad de isla del Coco, Región de La Mojana, Departamento de Sucre, Colombia, Revista Biología. 2003; 17(2): 126-33.

5. De La Ossa VJ, De La Ossa-Lacayo A. Cacería de subsistencia en San Marcos, Sucre, Colombia, Revista Colombiana de Ciencia Animal. 2011; 3(2):213-24. https://doi.org/10.24188/recia.v3.n2.2011.367.

6. De La Ossa J, Olivero-G G, Ruiz J.G. Utilización de quelonios de interés económico en el municipio de Caimito, Sucre, Colombia, Revista Colombiana de Ciencia Animal. 2011; 3(1):3-4. https://doi.org/10.24188/recia.v3.n1.2011.245.

7. Casta-o-MO V, Cárdenas-AG, Gallego-GN, Rivera-DO. Protección y conservación de los quelonios continentales en el departamento de Córdoba. Universidad Nacional de Colombia, Instituto de Ciencias Naturales - Corporación Autónoma Regional de los Valles del Sinú y San Jorge CVS. Convenio No. 28: Bogotá; 2005. p. 1-185.

8. De Ambiente M, Vivienda y Desarrollo Territorial. Plan de manejo orientado al uso sostenible de la tortuga hicotea en Colombia. Fundacion Universidad de America; 2009. p. 1-76.

9. Páez VP (Duméril, 1852). Libro rojo de reptiles de Colombia. Morales-Betancourt MA, Lasso CA, Páez V P, Bock BC. (Editors). Instituto de Investigación de Recursos Biológicos Alexander von Humboldt, Universidad de Antioquia: Colombia; 2015. p. 137-40.

10. Páez VP, Gallego-García, N, Restrepo A. Podocnemis Lewyana. The IUCN Red List of Threatened Species.e.T17823A1528580: Gland; 2016.

11. Casta-o-MOV. Rhinoclemmys melanosterna. In Casta-oMOV (Ed.). Libro rojo de reptiles de Colombia. Libros rojos de especies amenazadas de Colombia. Instituto de Ciencias Naturales Universidad Nacional de Colombia, Ministerio del Medio Ambiente, Conservación Internacional Colombia: Bogotá; 2002.

12. Tortoise and Freshwater Turtle Specialist Group. Rhinoclem Mysannulata (errata version published in 2016). The IUCN Red List of Threatened Species; 1996.

13. Peres CA. Effects of hunting on western Amazonian primate community, Biological Conservation. 1990; 54(1):47-59. https://doi.org/10.1016/0006-3207(90)90041-M.

14. Alvard M. Conservation by native peoples: Prey choice in a depleted habitat, Human Nature. 1994; 5(2):127-54. https:// doi.org/10.1007/BF02692158/. PMid: 24214538.

15. Redford KH, Sanderson S. Stracting human from nature, Conservation Biology. 2000; 14(5):1362-64. https://doi. org/10.1046/j.1523-1739.2000.00135.x.

16. Winter KA. Subsistence use of terrestrial and aquatic animal resources in the tierra comunitaria de Origenitonama of lowland Bolivia. Ph.D Dissertation, University of Georgia: Athens; 2002.
17. Holdridge LR. Life zone ecology. Tropical Science Center: San José, Costa Rica; 1967. PMid: 6053641.

18. Cortés-Gregorio I, Pascual-Ramos E, Medina-Torres SM, Sandoval-Forero EA, Lara-Ponce E, Pi-a-Ruíz HH, Martínez-Ruíz R, Rojo-Martínez GE. Etnozoología del pueblo Mayo-Yoreme en el norte de Sinaloa: uso de vertebrados silvestres, Agricultura, Sociedad y Desarrollo. 2013; 10:335-58.

19. Margoluis R, Salafsky N. Medidas de éxito. Dise-o, manejo y monitoreo de proyectos de conservación y desarrollo. Island Press: Washington; 1998.

20. Gibbons JW. Recommendations for future research on fresh waters turtles: What are the question? Washington: Smith Institute Press; 1990. 311-17.

21. De La Ossa VJ, Vogt RC. Efecto de substitución. Una expresión del agotamiento poblacional de quelonios en Barcelos, Amazonas, Brasil. Revista de la, Asociación Colombiana de Ciencias Biológicas. 2010; 22:61-67.

22. Zar JH. Biostatistical Analysis. 3rd Edition. Prentice Hall: México; 1996.

23. Valencia-Parra E, De La Ossa VJ. Patrones de uso de fauna silvestre en el bajo río San Jorge, Sucre, Colombia, Revista Colombiana de Ciencia Animal. 2016; 8(Supl):276-82. https://doi.org/10.24188/recia.v8.n0.2016.382.

24. David DJ, Aguirre-Ramírez NJ, Vélez-Macías FB. Relación de las poblaciones humanas con los mamíferos silvestres del Sistema Cenagoso de Ayapel, Colombia, Biocenosis. 2016; 31(1-2):46-57.

25. Vélez Sosa DM. Diagnóstico del uso de fauna silvestre en las veredas mundo nuevo, el Manzano y la Jangada en la Reserva Forestal Protectora de los ríos Blanco y Negro en el municipio de la Calera (Cundinamarca - Colombia). MEMORIAS: Manejo de Fauna silvestre en Amazonia y Latinoamérica; 2004. p. 1-6.

26. Vázquez García V, Godínez Guevara ML. Cambio social y estatus masculino en la cacería indígena. Un estudio de caso del sureste veracruzano.Relaciones, Estudios de Historia y Sociedad. 2005; 26(103):134-67.

27. Lira-Torres I, Briones-Salas M, Gómez De Anda FR, OjedaRamírez D, Peláez Acero A. Uso y aprovechamiento de la fauna silvestre en la selva Zoque, México, Acta Zoológica Mexicana. 2014; 30(1):74-90. https://doi.org/10.21829/ azm.2014.301130.

28. Cárdenas-Arévalo G, Páez VP. Biología y conservación de las tortugas continentales de Colombia, Serie Editorial Recursos Hidrobiológicos y Pesqueros Continentales de Colombia. Instituto de Investigación de Recursos Biológicos Alexander von Humboldt. Bogotá; 2012. p. 171-86.

29. Puentes V, Polo CJ, Roldán AM, Zuluaga PA (Eds.). Artes y métodos de pesca en Colombia. Autoridad Nacional de 
Acuicultura y Pesca - AUNAP. Conservación Internacional Colombia: Bogotá; 2014. p. 1-218.

30. Medem F. La reproducción de la "icotea" (Pseudemys scripta callirostris), (Testudines: Emydidae), Caldasia. 1975; 11:83-101.

31. Ojasti J. Manejo de fauna silvestre neotropical. Fernando TrujilloInstituto de Zoologia Tropical Universidad Central de Venezuela Caracas, Venezuela. Smithsonian Institution/ MAB: Washington; 2000. p. 1-304.

32. Hernández O, Espín R. Efectos del reforzamiento sobre la población de tortuga Arrau (Podocnemisexpansa) en el Orinoco Medio, Venezuela, Interciencia. 2006; 31(6):424-30.

33. González-Zárate A, Montenegro O, Casta-o-Mora OV, Vargas-Ramírez M. Abundancia, estructura poblacional y conservación de Podocnemis Lewyana (Podocnemididae) en el río Prado, Colombia, Acta Biológica Colombiana. 2014; 19(3):351-61. https://doi.org/10.15446/abc.v19n3.41565.
34. Aguilera GE, Neira MFH. Proyecto caracterización biofísica, socioeconómica y tecnológica, de los sistemas de producción agropecuarios de la región de La Mojana. Sistema de producción de pesca y caza y Caracterización del uso de fauna y flora. Reporte final. Corpoica, Programa Nacional de Agroecosistemas: Bogotá;1999.

35. De La Ossa VJ. Manejo de Fauna silvestre tropical. En: Programa de Desarrollo Sostenible de la Región de La Mojana. DNP, FAO, Bogotá, Colombia; 2003. p. 10-39.

36. Baptiste-Ballera LG, Hernández PS, Polanco OR, Quiceno MMP. La fauna silvestre colombiana: una historia económica y social de un proceso de marginalización; 2017. p. 1-50.

37. Guerra Roa MM, Naranjo Pi-era EJ, Limón Aguirre F, Mariaca Méndez R. Factores que intervienen en la regulación local de la cacería de subsistencia en dos comunidades de la selva Lacandona, Chiapas, México, Etnobiología. 2004; 4:1-18. 